DIGITAL COMMONS
@ UNIVERSITY OF SOUTH FLORIDA

Volume 6

Issue 1 Volume 6.1 (Spring 2016)

\section{ABO: Interactive Journal for Women in the Arts, 1640-1830}

2016

\title{
Review of Dale Townshend and Angela Wright, eds., Ann Radcliffe, Romanticism and the Gothic
}

\author{
Ellen Malenas Ledoux \\ Rutgers University - Camden, eledoux@rutgers.edu
}

Follow this and additional works at: https://digitalcommons.usf.edu/abo

Part of the Dramatic Literature, Criticism and Theory Commons, Education Commons, Feminist, Gender, and Sexuality Studies Commons, and the Literature in English, British Isles Commons

\section{Recommended Citation Article 3. \\ http://dx.doi.org/10.5038/2157-7129.6.1.3 \\ Available at: https://digitalcommons.usf.edu/abo/vol6/iss1/3}

Ledoux, Ellen Malenas (2016) "Review of Dale Townshend and Angela Wright, eds., Ann Radcliffe, Romanticism and the Gothic," ABO: Interactive Journal for Women in the Arts, 1640-1830: Vol.6: Iss.1,

This Reviews is brought to you for free and open access by Digital Commons @ University of South Florida. It has been accepted for inclusion in ABO: Interactive Journal for Women in the Arts, 1640-1830 by an authorized administrator of Digital Commons @ University of South Florida. For more information, please contact digitalcommons@usf.edu. 
Review of Dale Townshend and Angela Wright, eds., Ann Radcliffe, Romanticism and the Gothic

\section{Keywords}

ann radcliffe, feminist criticism, book history, romanticism, gothic novel

\section{Creative Commons License}

(c) $($ ) $\Theta$

This work is licensed under a Creative Commons Attribution-No Derivative Works 3.0 License. 
Dale Townshend and Angela Wright, eds. Ann Radcliffe, Romanticism and the Gothic. Cambridge: Cambridge UP, 2014. Xv + 257pp. Index. ISBN: 978-1-107-03283-5.

Reviewed by Ellen Malenas Ledoux

Rutgers University-Camden

Ann Radcliffe, Romanticism and the Gothic forms one part of several academic events designed to celebrate and to re-evaluate the impact of Ann Radcliffe 250 years since her birth, including special issues on Radcliffe in Women's Writing and a "Study Day" at Chawton House Library. The book was launched at its companion conference, Radcliffe at 250, held at the University of Sheffield in June 2014 and organized by the book's editors, Dale Townshend and Angela Wright. For anyone not lucky enough to attend the conference, which featured keynotes by Emma Clery, Fred Botting, and Jane Stabler, the book includes essays on similar topics by many of the eminent Radcliffe scholars who presented. Perhaps the volume's origination in a retrospective explains why the individual essays called to mind earlier important and highly influential work by some of these contributors, but not the "cutting-edge" scholarship promised on the volume's back cover copy. The essays by JoEllen DeLucia, Samuel Baker, and Diego Saglia form notable exceptions, as they offer fresh approaches and new readings that contain important insights even for seasoned devotees of Radcliffe.

What the volume lacks in innovation, it makes up for in usefulness. Because it collects almost all of the important discussions about Radcliffe in one place, it would be an extremely important read for graduate students or more advanced scholars embarking on a serious study of Radcliffe or the Gothic mode. For academic libraries, this book is a wise purchase. The book usefully groups its thirteen chapters into three main sections, which can roughly be described as context, textual readings, and "afterlives." The first section discusses the literary and cultural milieu in which Radcliffe was writing and how it contributed to her canonization and celebrity. Chapter One, written by Townshend and Wright, provides a fairly orthodox reading of Scott's seminal role in establishing Radcliffe as an "original" artistic voice. Although most of the reception history this chapter contains is available elsewhere (see The Critical Response to Ann Radcliffe, 1993), the chapter's exegesis of this reception creates an important baseline for approaching the essays to follow. Chapter Two by Joe Bray uses literary representations of portraiture to discuss how Radcliffe draws upon her predecessors within the Gothic novel genre (Horace Walpole and Sophia Lee) to highlight the subjectivity of individual perception and to reject empiricism as a reliable tool for understanding human character. In Chapter Three, Edward Jacobs demonstrates the seminal role Radcliffe's work had in transforming print culture through a unique combination of commercial success and generic innovation. James Watt argues in Chapter Four that Radcliffe's politics ought to be read as more reformist than her major biographers have posited and that some of her "interest in social process" can be seen in her novel's non-linear narrative style (67). Yet, because Radcliffe left us so little extra-textual material, it is quite difficult to define precisely her political intervention.

The second section offers what the editors call "a fresh and systematic re-examination of Radcliffe's oeuvre" (xiii) vis-à-vis Romantic aesthetics. The "systematic" aspect of this grouping proved the most compelling, as it offered readings of Radcliffe's early, posthumous, and 
non-Gothic work, which rarely attract scholarly attention. In Chapter Five, Alison Milbank addresses Radcliffe's first two novels, The Castles of Athlin and Dunbayne and A Sicilian Romance, which are typically regarded as trial precursors worthy only of notice in that they render possible her later masterpieces: The Romance of the Forest, The Mysteries of Udolpho, and The Italian. Here, Milbank reclaims their purpose, suggesting they anticipate "in certain ways, the Romantic visionary perspective" (86), especially in their presentation of landscape. Diane Long Hoeveler takes on the first of Radcliffe's major works, The Romance of the Forest, offering a standard reading of Radcliffe's sentimental heroine and the symbolic function of Gothic space in Chapter Six. In Chapter Seven, Robert Miles approaches Udolpho as a test case for examining Romantic aesthetics as a response to secularization. Chapter Eight is the most generative essay of this section. Here, JoEllen DeLucia takes on Radcliffe's travel writing, demonstrating how Radcliffe eschewed the genre's conventions of indulging in abstract meditations on the sublime and the picturesque in favor of finding a unique voice that emphasized "the larger devastation created by contemporary politics and history" (137). In Chapter Nine, Jerrold E. Hogle posits The Italian as not just a self-conscious response to Lewis's The Monk, but also, on a more profound level, an attempt to reconcile the two forms of romance in the way that Horace Walpole ambitiously outlines in his second preface to The Castle of Otranto. This section is rounded out by Samuel Baker's treatment of the posthumous fragment Gaston de Blondeville and the texts that accompanied its publication event. Here, Baker argues that the little-studied fragment is worth a closer look in that its publication and its content have important implications for understanding how gothic and novelistic convention progressed in the twenty years between the fragment's writing and its dissemination.

Section Three, which is the freshest and most provocative part of the book, discusses Radcliffe's "afterlife"; the impact her work had on the poetry and prose of others as well as the ways in which her work lends itself to endless adaptation. In Chapter Eleven, Jane Stabler examines Radcliffe's poetry, not only as a formal innovation in the novel, i.e. interpolated verse (as is most common), but on its own terms with attention paid to its "craftsmanship" and "engagement with contemporary aesthetic and cultural debates" (186). Analyzing the unauthorized 1816 Poems of Mrs. Ann Radcliffe, Stabler contends that the mechanical and thematic repetitions in Radcliffe's poetry highlight "the tension between masculine Romantic poetry and female experience" (189). Sue Chaplin assesses Radcliffe's legacy within prose fiction in Chapter Twelve, particularly in relation to the "masculine" genre of historical romance associated with Sir Walter Scott. The volume concludes with Diego Saglia's much-needed discussion of stage adaptations of Radcliffe's work. He argues that rather than merely being derivative melodramas, these "theatrical translations" employed the form and technique of stagecraft to represent the "historically and ideologically specific contents of [Radcliffe's] fiction" (220). Rather than literalizing narratives that depend so highly on the imagination, the stage, paradoxically, created physical spaces that were cognitively disjunctive, what Saglia refers to as "stage epistemologies" (226).

This essay, along with others that address genres beyond the novel, proved the most original interventions the volume makes. In addition, the discussions by Edward Jacobs and Samuel Baker that approach Radcliffe's publications as cultural events offer important readings for anyone interested in women's formative role in print culture and book history. Overall, the book provides a solid foundation for anyone who wishes to understand the most important debates that 
have been occurring about Radcliffe as a figure central to the Gothic mode and the expanding definition of Romanticism over the past twenty years. 